\title{
Grzegorz WojciechowsKi*
}

\section{STRUKTURA I KOMPETENCJE DYKASTERII DS. INTEGRALNEGO ROZWOJU CZEOWIEKA}

Jednym z podstawowych obowiązków wszystkich wiernych (christifidelium) jest nakaz prowadzenia świętego życia, zgodnie z własną pozycją oraz przyczynianie się do ustawicznego wzrostu i rozwoju Kościoła (kan. 210) ${ }^{1}$. To powszechne powołanie do świętości nierozerwalnie łączy się z obowiązkiem Kościoła uwidaczniającym się w trosce o rozwój każdego człowieka żyjącego na ziemi. Już Paweł VI w swojej encyklice Populorum progressio ${ }^{2}$ zauważył, że „Rozwój ludów, szczególnie tych, które usiłują uwolnić się od nieszczęść głodu, nędzy, lokalnych epidemii i ciemnoty, które domagają się pełniejszego udziału w dobrach stworzonych przez cywilizację i żądaja, by ich ludzkie wartości były w praktyce bardziej uznawane, które wreszcie stale kierują swą myśl ku większemu postępowi, rozwój tych właśnie ludów jest przedmiotem żywej i bacznej uwagi Kościoła katolickiego". Dlatego też Magisterium Kościoła wypełniając swoją misję głoszenia Ewangelii wśród wszystkich narodów świata, dba o wzrost świętości swoich członków, który przejawia się w nieustannym zmaganiu o szczęście wszystkich ludzi, o postęp całej ludzkości, a w konsekwencji o zbawienie niezliczonej rzeszy ludzkiej.

* Ks. dr hab., Katolicki Uniwersytet Lubelski Jana Pawła II; e-mail: gwojcie@kul.pl.

${ }^{1}$ Codex Iuris Canonici auctoritate Ioannis Pauli PP. II promulgatus. 25.01.1983, AAS 75(1983), pars II, 1-324; tekst w j. polskim: Kodeks Prawa Kanonicznego. Przekład polski zatwierdzony przez Konferencję Episkopatu, Poznań 1984.

2 Paulus VI, Litterae encyclicae "Populorum progressio". Ad Episcopos, ad Sacerdotes, ad Religiosos, ad Christifideles totius Catholici Orbis, itemque ad universos bonae voluntatis homines: de populorum progressione promovenda. 26.03.1967, AAS 59(1967) 257-299; tekst w j. polskim: Paweł VI, Populorum progressio, Wrocław 1999. 
Rozwój człowieka powinien być „integralny, to znaczy winien przyczyniać się do rozwoju każdego człowieka i całego człowieka" $(P P, 14)$. Nie jest on jedynie problemem natury ekonomicznej, lecz związany jest z osobą ludzką - jej nieustannym nastawieniem na własny rozwój i „uzdolnieniem do rozwijania twórczych energii, a także $z$ formacją etyczną i odpowiedzialnością moralną za podejmowane działania"”3. Dlatego też, zawiera on w sobie troskę o bliźnich, okazywanie im bezpośredniej pomocy oraz uwrażliwianie otoczenia na potrzeby ludzi.

Benedykt XVI rozwijając myśl Pawła VI, stwierdził, że jego wizja rozwoju zakładała ,jako cel uwolnienie narodów przede wszystkim z głodu, nędzy, chorób endemicznych i analfabetyzmu. Z punktu widzenia ekonomicznego oznaczało to ich czynne uczestnictwo i na równych warunkach $\mathrm{w}$ międzynarodowym procesie ekonomicznym; z punktu widzenia społecznego oznaczało to ich ewolucję w kierunku społeczeństw wykształconych i solidarnych; z punktu widzenia politycznego oznaczało to umocnienie rządów demokratycznych mogących zapewnić wolność i pokój"4

Pragnienie Pawła VI jest również aktualne i w dzisiejszych czasach, w których globalizacja, przepływ ludzi, problem migracyjny, szerzenie się niesprawiedliwości społecznej wymagają od Kościoła nowego i świeżego spojrzenia na problemy współczesnego świata. Dlatego też Franciszek, dostrzegając nieustanną potrzebę pobudzania rozwoju człowieka powołał do życia nową jednostkę administracyjną w strukturze Kurii Rzymskiej Dykasterię ds. promowania integralnego rozwoju człowieka, która - jak sam podkreślił - „będzie szczególnie kompetentna w kwestiach dotyczących migracji, potrzebujących, chorych i wyłączonych, zmarginalizowanych i ofiar konfliktów zbrojnych oraz katastrof naturalnych, więźniów, bezrobotnych i ofiar jakiejkolwiek formy niewolnictwa i tortury" ${ }^{\prime \prime}$.

${ }^{3}$ M. Antoniewicz, Integralny rozwój człowieka w ujęciu "Caritas in veritate" Benedykta XVI, „Studia Gnesnensia” 2010, t. 24, s. 266.

4 Benedictus XVI, Litterae encyclicae "Caritas in Veritate" de humana integra progressione in caritate veritateque. 29.06.2009, AAS 101(2009) 641-709; tekst w j. polskim: Benedykt XVI, Encyklika "Caritas in Veritate" Ojca Świętego Benedykta XVI do Biskupów, Prezbiterów i Diakonów, do osób konsekrowanych $i$ wszystkich ludzi dobrej woli o integralnym rozwoju ludzkim $w$ miłości i prawdzie, 21, Skultuna 2012, s. 23.

${ }^{5}$ Franciscus, Litterae apostolicae motu proprio datae "Humanam progressionem" quibus Dicasterium ad integram humanam progressionem fovendam constituitur. 17.08.2016, „L'Osservatore Romano” 1.09.2016, s. 6; tekst w j. polskim: Franciszek, Integralny rozwój człowieka w świetle ewangelii. List apostolski w formie «motu proprio», którym ustanawia Dykasterię ds. Integralnego Rozwoju Człowieka, „L'Osservatore Romano” [wyd. pol.] 36(2016), nr 9, s. 8 . 
Niniejszy artykuł ma celu ukazanie struktury i kompetencji nowopowstałej dykasterii, która wpisuje się w szeroki plan papieża zreformowania Kurii Rzymskiej w taki sposób, aby odpowiadając na potrzeby czasu i miejsca mogła ona lepiej realizować swoje główne zadanie, jakim jest niesienie pomocy Biskupowi Rzymu w załatwianiu spraw Kościoła powszechnego (kan. 360) ${ }^{6}$.

\section{Skład osobowy Dykasterii}

Zgodnie ze Statutem Dykasterii ds. promowania integralnego rozwoju człowieka ${ }^{7}$ promulgowanym dnia 17 sierpnia 2016 r. ad experimentum przez papieża Franciszka, w jej skład wchodzą: prefekt, sekretarz oraz przynajmniej jeden podsekretarz, a także członkowie, których liczba nie została uszczegółowiona. Członkowie, oprócz prefekta, mogą wywodzić się zarówno ze stanu duchownego, jak i świeckiego.

Zgodnie z przyjętą polityką kadrową, jaka od dłuższego czasu charakteryzuje Kurię Rzymska, powinni oni pochodzić z różnych części świata, co ma podkreślić uniwersalny (powszechny) charakter Kościoła katoli-

${ }^{6}$ Papież Franciszek w ten sposób chce uczynić zadość postulatowi, jaki został wystosowany podczas Soboru Watykańskiego II, zgodnie z którym: „Ojcowie świętego Soboru wyrażają zatem życzenie, aby te dykasterie, które Biskupowi Rzymu i pasterzom Kościoła bezsprzecznie przychodziły z wydatną pomoca, zostały jednak na nowo zorganizowane i bardziej dostosowane do wymagań czasu, krajów i obrządków, zwłaszcza w tym, co się tyczy ich liczby, nazwy, kompetencji i im właściwego sposobu postępowania oraz zorganizowanej między nimi współpracy", Sacrosanctum Concilium Oecumenicum Vaticanum II, Decretum de pastorali episcoporum munere in Ecclesia "Christus Dominus". 28.10.1965, 9, AAS 58(1966) 673-696; tekst w j. polskim: Sobór Watykański II, Dekret o pasterskich zadaniach biskupów w Kościele „Christus Dominus”, [w:] Sobór Watykański II. Konstytucje, dekrety, deklaracje, Poznań 2002, s. 236-258, tu, 9, s. 239. Szerzej o nowych instytucjach Kurii Rzymskiej, zob. Franciscus, Litterae apostolicae motu proprio datae "Sedula Mater" quibus dicasterium pro laicis, familia et vita constituitur. 15.08.2016, „L'Osservatore Romano" 17-18.08.2016, s. 8; tekst w j. polskim: Franciszek, Kościót, troskliwa Matka. List apostolski w formie «motu proprio», na którego mocy zostaje ustanowiona Dykasteria ds. Świeckich, Rodziny i Życia, "L'Osservatore Romano" [wyd. pol.] 36(2016), nr 9, s. 8; A. Romanko, Reforma Urzędu Informacji Finansowej i Instytutu Dzieł Religijnych, „Prawo Kanoniczne” 2016, nr 3, s. 122-142; taż, Nowe struktury ekonomiczno-administracyjne w Kurii Rzymskiej, „Roczniki Nauk Prawnych” 2016, nr 3, s. 99-120.

${ }^{7}$ Francesco, Statuto del Dicastero per il servizio dello sviluppo umano integrale. 17.08.2016, „L'Osservatore Romano” 1.09.2016, s. 6 (dalej Statut). 
ckiego (art. $2 \S 3$ Statutu) ${ }^{8}$. Dykasteria posiada również swoich konsultorów oraz urzędników (art. $2 \S 4$ Statutu). Statut nie zawiera szczegółowych przepisów dotyczących wymogów, kadencji oraz kompetencji poszczególnych członków dykasterii ${ }^{9}$. Papież zaznacza jedynie, że z wyłączeniem prefekta, wszystkie urzędy w dykasterii mogą sprawować wierni świeccy (art. $2 \S 1-2$ Statutu). Dlatego też w tym miejscu należy sięgnąć do norm zawartych w konstytucji apostolskiej Pastor bonus ${ }^{10}$, w której określono ogólne ramy działalności całej Kurii Rzymskiej. Zgodnie z nią członkowie dykasterii powoływani są przez Biskupa Rzymu na 5 letnią kadencję. Swój urząd tracą $\mathrm{z}$ momentem osiągnięcia osiemdziesiątego roku życia (art. $5 \S 1 P B$ ). Powinni oni posiadać odpowiednie cechy oraz być ekspertami w dziedzinach, w których kompetentna jest dykasteria (art. $2 \S 2$ Statutu).

\subsection{Prefekt}

Dykasterii ds. promowania zrównoważonego rozwoju człowieka przewodniczy prefekt, który mianowany jest przez Biskupa Rzymu. Powinien on być osobą duchowna, bowiem "to, co domaga się wykonywania władzy rządzenia, jest zarezerwowane tym, którzy posiadają święcenia" (art. 7 PB). W praktyce przyjęło się, że tytuł prefekta zarezerwowany jest

${ }^{8}$ O uniwersalności struktur Kurii Rzymskiej wspomniał już Sobór Watykański II: „Ponadto, ponieważ te dykasterie zostały ustanowione dla dobra całego Kościoła powszechnego, jest pożądane, aby ich członkowie, urzędnicy i konsultorzy oraz legaci papiescy, na ile to jest możliwe, byli w większym stopniu dobierani z różnych regionów Kościoła, tak aby urzędy Kościoła katolickiego, czyli centralne organy, ukazywały jego prawdziwie powszechny charakter. [...] Ojcowie soborowi uważają wreszcie, iż będzie rzeczą bardzo pożyteczną, jeśli te dykasterie w większym stopniu będą wysłuchiwać ludzi świeckich, odznaczających się cnotą wiedzą i doświadczeniem, tak aby i oni mieli stosowny udział w sprawach dotyczących Kościoła", Sobór Watykański II, Dekret o pasterskich zadaniach biskupów w Kościele "Christus Dominus”, 10, s. 239.

9 Zob. A. Zanotti, "A chiare lettere - confronti". A proposito di un diritto canonico periferico: ovvero il rischio della perifericità del diritto canonico, "Stato, Chiese e Pluralismo Confessionale. Rivista telematica" 2017, nr 2, s. 11, http://www.statoechiese.it/images/uploads/ articoli_pdf/zanotti_a_proposito.pdf [dostęp: 4.10.2017 r.].

${ }^{10}$ Ioannes Paulus II, Constitutio apostolica "Pastor Bonus". 28.06.1988, AAS 80(1988) 841912; tekst w j. polskim: Jan Paweł II, Konstytucja apostolska o Kurii Rzymskiej „Pastor Bonus", [w:] W. Kasprzak, M. Sitarz (red.), Ustrój Hierarchiczny Kościoła. Wybór źródet, Lublin 2006, s. 217-257 (dalej PB). 
wyłącznie osobom wyniesionym do godności kardynalskiej ${ }^{11}$. Kardynał prefekt w momencie ukończenia siedemdziesiątego piątego roku życia proszony jest o złożenie rezygnacji na ręce papieża, który po rozważeniu wszystkich okoliczności zadecyduje o dalszym pełnieniu tej funkcji. Jeśli zdarzyłoby się, że prefektem jest duchowny nie wyniesiony do godności kardynalskiej, z mocy prawa traci urząd po uzyskaniu wskazanego wyżej wieku (art. 5 § $2 P B$ ). Głównym zadaniem prefekta jest funkcja reprezentacyjna, urzeczywistniająca się $\mathrm{w}$ występowaniu na forum zewnętrznym $\mathrm{w}$ jej imieniu (art. 4 PB). Z racji swego urzędu powinien on również koordynować pracę dykasterii oraz wyznaczać kierunki jej rozwoju.

\subsection{Sekretarz i podsekretarze}

Sekretarz oraz podsekretarze mianowani są na urząd przez papieża na okres pięciu lat (art. $5 \S 1 P B$ ). Jeśli w trakcie pełnienia urzędu osiągnęli by wiek siedemdziesięciu pięciu lat, z mocy prawa tracą swój urząd (art. $5 \S 2 P B$ ). Sekretarz, wspierany przez podsekretarza, świadczy pomoc prefektowi lub przewodniczącemu $\mathrm{w}$ załatwianiu spraw danej dykasterii i kierowaniu personelem (art. 4 PB). Pomimo, że Statut Dykasterii nie wspomina o tym, to do zadań sekretarza należy również troska o archiwum dykasterii, w którym przechowuje się nadesłane pisma oraz kopie pism wysyłanych (art. $10 P B$ ). Archiwum musi znajdować się w bezpiecznym miejscu oraz być zabezpieczone przed dostępem osób nieuprawnionych ${ }^{12}$.

\subsection{Konsultorzy i inni urzędnicy}

Dykasteria posiada swoich własnych konsultorów oraz innych urzędników, którzy powinni pochodzić z różnych części świata (art. 2 § 3 Statutu). Na konsultorów mianuje się zarówno duchownych, jak i świeckich, którzy odznaczają się wiedzą oraz roztropnością (art. 8 PB). Urzędnikami mogą zostać wierni, którzy cechują się cnota, roztropnościa, potrzebną

${ }^{11}$ Mimo iż nie ma wprost nakazu powoływania na urząd prefekta dykasterii Kurii Rzymskiej wyłącznie kardynałów to praktyka wskazuje właśnie na taką rezerwację tego urzędu, zob. Annuuario pontificio per l'anno 2017, Città del Vaticano 2017.

${ }^{12}$ Szerzej zob. Ioannes Paulus II, Legge sugli archivi della Santa Sede. 21.03.2005, AAS 97(2005) 355-376. 
wiedza, która musi zostać potwierdzona odpowiednimi tytułami akademickimi. Zdatność kandydatów można sprawdzić poprzez egzamin lub w inny odpowiedni sposób (art. 9 PB). Zatrudnienie powinno odbywać się na podstawie Regulaminu Ogólnego Kurii Rzymskiej ${ }^{13}$ oraz Regulaminu w sprawie rekrutacji świeckich pracowników przy Stolicy Apostolskiej ${ }^{14}$.

\section{Struktura wewnętrzna dykasterii}

Papież Franciszek wraz z powołaniem Dykasterii ds. promowania integralnego rozwoju człowieka, ustanowił w jej łonie trzy Komisje, które mają odzwierciedlać zadania jakie na niej spoczywają. Są to: Komisja ds. Dobroczynności, Komisja ds. Ekologii oraz Komisja Pracowników Opieki Zdrowotnej (art. $4 \S 5$ Statutu). Każda z tych struktur powinna posiadać swój własny statut, który wyznaczałby ramy jej pracy. Przewodniczy im prefekt dykasterii, który powinien zwołać je, gdy uzna to za stosowne bądź konieczne. Zadaniem tych Komisji, podobnie jak całej Dykasterii, jest wyrażanie troski Stolicy Apostolskiej o sprawy sprawiedliwości i pokoju, w tym związane z migracją, zdrowiem, pracami charytatywnymi i opieką nad stworzeniem (art. $1 \S 1$ Statutu). W ramach Dykasterii utworzona została również Sekcja ds. Uchodźców i Imigrantów, jako odpowiedź papieża na występujący obecnie w Europie kryzys migracyjny, powstały wskutek znacznego przepływu imigrantów z terenów Afryki i Azji15. Z tego też względu, przewodniczenie tej sekcji zostało tymczasowo powierzone samemu Biskupowi Rzymu (art. $1 \S 4$ Statutu).

Utworzenie powyższej struktury wewnętrznej Dykasterii spowodowane zostało przejęciem przez nią kompetencji, jakie wcześniej posiadały Papieska Rada Iustitia est Pax, Papieska Rada Cor Unum, Papieska Rada Duszpasterstwa Migrantów i Podróżnych oraz Papieska Rada Duszpa-

${ }^{13}$ Secretaria Status, Regolamento Generale della Curia Romana. 30.04.1999, AAS 91(1999) 629-699.

${ }^{14}$ Secretaria Status, Regolamento della Commissione indipendente di valutazione per le assunzioni di personale laico presso la Sede Apostolica. 30.11.2012, AAS 105(2013) 84-92.

15 Podczas audiencji 17 października 2016 r. papież Franciszek podkreślił, że aktualna sytuacja migracyjna to największy kryzys humanitarny od czasów II wojny światowej, zob. Francis, Speech Address of his Holiness Pope Francis to the Members of the European Confederation and of the World Union of Jesuit Alumni and Alumnae, https://w2.vatican.va/content/ francesco/en/speeches/2016/september/documents/ papa-francesco [dostęp: 1.10.2017 r.]. 
sterstwa Pracowników Służby Zdrowia (art. 5 Statutu) ${ }^{16}$. Wynika to również ze szczególnego zainteresowania powyższymi zagadnieniami przez Ojca Świętego Franciszka ${ }^{17}$.

\subsection{Powiązania Dykasterii z instytucjami Kurii Rzymskiej}

Dykasteria, ze względu na zakres spraw jaki pozostaje w jej gestii, została zobowiązana do działania w ścisłej współpracy z II Sekcją Sekretariatu Stanu, przy wzajemnym respektowaniu kompetencji innych ${ }^{18}$. Sekcja ta ma wyłączne kompetencje w sprawach mających wpływ na stosunki z państwami i innymi międzynarodowymi instytucjami publicznymi (art. $4 \S 1$ Statutu). Dlatego też Dykasteria powinna współdziałać $\mathrm{z}$ tą instytucją w szczególności w odniesieniu do wydawanych przez nią

16 Z dniem 1 stycznia 2017 r., wskazane instytucje Kurii Rzymskiej przestały istnieć, a jej kompetencje zostały wchłonięte przez nowopowstałą Dykasterię, dlatego też art. 142153 konstytucji Pastor Bonus zostały zniesione.

17 Kwestie dobroczynności i zwrócenia uwagi Kościoła na ubogich Franciszek poruszył w swojej pierwszej adhortacji apostolskiej Evangelii gaudium, zob. Franciscus, Adhortatio apostolica "Evangelii gaudium". 24.11.2013, AAS 105(2013) 1019-1137; tekst w j. polskim, zob. Franciszek, Adhortacja apostolska "Evangelii gaudium” o głoszeniu Ewangelii w dzisiejszym świecie, Kraków 2014); nt. ekologii w encyklice Laudato si', w której przestrzegał przed nadmiernym wyzyskiwaniem zasobów naturalnych oraz zagrożeniami jakie niesie ze sobą zanieczyszczanie środowiska i globalne ocieplenie, zob. Franciscus, Litterae encyclicae "Laudato si"” de communi domo colenda. 25.05.2015, AAS 107(2015) 847-945; tekst w j. polskim, zob. Franciszek, Encyklika "Laudato si"” poświęcona trosce o wspólny dom, Częstochowa 2015); o potrzebie troski wobec imigrantów, osób przesiedlonych, uchodźców i ofiar handlu ludźmi w Orędziu na 104 Światowy Dzień Migranta i Uchodźcy, zob. Franciszek, Przyjmować, chronić, promować i integrować imigrantów i uchodźców. Orędzie papieża Franciszka na Światowy Dzień Migranta i Uchodźcy 2018 r. 15.08.2017, „L'Osservatore Romano” [wyd. pol.] 37(2017), nr 9, s. 4-7.

${ }^{18}$ Sekretariat Stanu jest jedną z najstarszych i najważniejszych instytucji Kurii Rzymskiej. Jego początki związane były z ustanowieniem przez papieża Innocentego VIII Sekretariatu Apostolskiego, który wydzielony został z Kancelarii Apostolskiej, zob. Innocentus VIII, Non debet reprehensibile. 31.12.1487, [w:] Bullarum Diplomatum et Privilegiorum Sanctorum Romanum Pontificum, t. 5, Augustae Taurinorum, Seb. Franco et Henrico Dalmazzo Editoribus, 1860, s. 330-339 - art. 2. Paweł VI konstyctucją apostolską Regimini Ecclesiae Universae, umieścił Sekretariat Stanu na czele wszystkich organów Kurii Rzymskiej, zob. Paulus VI, Constitutio apostolica de Romana Curia "Regimini Ecclesiae Universae". 15.08.1967, AAS 59(1967) 885-928; tekst w j. polskim, zob. Paweł VI, Konstytucja apostolska "Regimini Ecclesiae Universae", [w:] W. Kacprzyk, M. Sitarz (red.), Ustrój hierarchiczny Kościoła. Wybór źródet, Lublin 2006, s. 166-196 - art. 19 § 1. Szerzej o historii, zob. E. Sztafrowski, Kuria Rzymska. Studium historyczno-kanoniczne, Warszawa 1981, s. 35-37; P. Paupard, Watykan, Warszawa 1979, s. 64-65. 
oświadczeń publicznych (dokumenty lub oświadczenia), w sprawach dotyczących stosunków z rządami cywilnymi i innymi międzynarodowymi instytucjami publicznymi (art. $4 \S 2$ Statutu) oraz w sprawach uczestnictwa w delegacjach Stolicy Apostolskiej w spotkaniach międzyrządowych dotyczących spraw należących do jej kompetencji (art. 4 § 3 Statutu). Zakres kompetencji Dykasterii obejmuje bowiem materię wykraczającą poza ramy działalności narodowej, dlatego też jej praca musi być moderowana przez Sekretariat Stanu.

Ustawodawca ponadto postanowil, że Dykasteria ma utrzymywać bliskie relacje z Papieską Akademią Nauk Społecznych, zgodnie z jej statutem (art. 4 § 4 Statutu). Instytucja ta powołana do życia dnia 1 stycznia 1994 r. przez Jana Pawła II na mocy motu proprio Socialium Scientiarum ${ }^{19}$, zajmuje się promowaniem studiów i postępów z obszaru nauk społecznych, ekonomicznych, politycznych i prawnych. Wyniki jej prac mają stanowić pomoc Kościołowi w pogłębianiu i rozwijaniu katolickiej nauki społecznej.

Ze względu na zadanie rozpowszechniania idei związanych z dobroczynnościa, Dykasterii przyznano również odpowiednie kompetencje w zakresie koordynacji prac Caritas Internationalis, z zachowaniem norm zawartych w Statucie i Regulaminie Międzynarodowego Caritas ${ }^{20}$.

\subsection{Powiązania Dykasterii z innymi organizacjami}

Zgodnie ze Statutem, Dykasteria ds. promowania integralnego rozwoju człowieka reprezentuje Stolicę Apostolską w sprawach dotyczących tworzenia i nadzorowania międzynarodowych organizacji charytatywnych, fundacji i funduszy utworzonych w tym samym celu, określonych $\mathrm{w}$ ich statutach i w prawie powszechnym (art. 5 Statutu). W praktyce oznacza to, że prefekt Dykasterii występuje w imieniu Stolicy Apostolskiej za każdym razem, kiedy ta chce powołać do życia organizację zajmującą

19 Ioannes Paulus II, Litterae apostolicae "motu proprio" datae "Socialium scientiarum" quibus Pontificia Academia Scientiarum Socialium constituitur. 1.01.1994, AAS 86(1994) 209-212; tekst w j. polskim: Jan Paweł II, List apostolski "motu proprio", którym Ojciec Święty ustanawia Papieska Akademię Nauk Społecznych, "L'Osservatore Romano" [wyd. pol.] 15(1994), nr 3, s. 39-40.

${ }^{20}$ Regulamin Międzynarodowego Caritas zatwierdzony został na mocy dekretu Sekretariatu Stanu dniu 2 maja 2012 r. Do dekretu dołączono Status Caritas Internationalis wraz z Regulaminem, zob. Secretaria Status, Decreto. 2.05.2012, AAS 104(2012) 919-969. 
się tematyką związaną ze społeczną nauką Kościoła, bądź kiedy Stolica Apostolska chce przystąpić do już istniejących struktur. Dlatego też wypełniając swoją misję, powinna zachęcać i koordynować inicjatywy katolickich instytucji dbających o godność każdej osoby, a także pomagających ludziom w potrzebie, wśród których specjalne miejsce zajmują instytucje pomagające reagować na najbardziej naglące potrzeby, w szczególności związane z klęskami żywiołami i innymi kataklizmami (art. $3 \S 4$ Statutu). Z zadaniem tym wiąże się ścisła współpraca ze wszystkimi stowarzyszeniami publicznymi i prywatnymi w Kościele, których misja zbieżna jest z działalnością Dykasterii. Czołowe miejsce wśród tych instytucji zajmuje Caritas, działający w poszczególnych państwach. Może również rozpocząć dyskusję z przedstawicielami rządów cywilnych i innych międzynarodowych instytucji publicznych w celu promowania badań, pogłębiania wiedzy i świadomości publicznej w sprawach należących do jej kompetencji, przy poszanowaniu kompetencji innych urzędów Kurii Rzymskiej (art. $3 \S 5$ Statutu).

\section{Kompetencje}

Głównym celem powołania nowej struktury w łonie Kurii Rzymskiej, jest koordynacja wszelkich działań związanych z troską Stolicy Apostolskiej w sprawach dotyczących sprawiedliwości i pokoju, migracji, zdrowia i działalności charytatywnej (art. $1 \S 1$ Statutu). Cel ten ma zostać osiągnięty poprzez promowanie integralnego rozwoju człowieka w świetle Ewangelii. Dlatego też Dykasteria powinna utrzymywać ścisłe relacje z poszczególnymi konferencjami biskupów, oferując im swoją współpracę (art. 1 \& 2 Statutu) i wyrażając w ten sposób troskę Ojca Świętego o cierpiących, potrzebujących, chorych i wykluczonych, zmuszonych do ucieczki z ojczyzny, bezpaństwowców, zmarginalizowanych, ofiar uzbrojonych konfliktów i klęsk żywiołowych, uwięzionych, bezrobotnych, ofiar współczesnych form niewolnictwa i tortur oraz innych, których godność w jakikolwiek sposób zostaje zagrożona (art. $1 \S 3$ Statutu). Osiągnięcie powyższego założenia powinno nastąpić w oparciu o naukę społeczną Kościoła. Stąd Dykasteria ma za zadanie rozpowszechnianie jej w świecie i wypracowanie odpowiednich narzędzi oraz rozwiązań dzięki którym relacje społeczne, gospodarcze i polityczne byłyby coraz bardziej przenik- 
nięte duchem Ewangelii (art. 3 § 1 Statutu). Musi być ona zaangażowana we wspieranie wśród narodów: wrażliwości na pokój, zaangażowania w sprawiedliwość i solidarność z osobami szczególnie narażonymi, takimi jak emigranci i uchodźcy, zwłaszcza poprzez obchody Światowego Dnia Pokoju, Światowy Dzień Uchodźcy i Imigranta, Światowy Dzień Chorych (art. $4 \S 6$ Statutu).

Ponadto Dykasteria pełni również funkcję kontrolną poprzez gromadzenie informacji i badanie w poszczególnych rejonach świata: funkcjonowania wymiaru sprawiedliwości, rozwoju ludów, promowania i obrony godności ludzkiej i praw człowieka, takich jak prawa do pracy, w tym nieletnich; zjawiska migracji i wyzysku migrantów; zjawiska handlu ludźmi i zniewolenia; stosowania tortur i kary śmierci; problematyki rozbrojenia i kontroli zbrojeń, a także konfliktów zbrojnych i ich skutków dla ludności cywilnej i środowiska naturalnego (prawo humanitarne). Członkowie tej instytucji poprzez ocenę i analizę danych, mają informować zainteresowane instytucje konferencji biskupów o wyciągniętych wnioskach, aby mogły one $\mathrm{w}$ razie potrzeby interweniować bezpośrednio przy rządach krajowych (art. 3 § 2 Statutu). Z powyższym zadaniem wiąże się kolejny cel powołania Dykasterii, jakim jest zapewnienie Kościołom lokalnym skutecznej i odpowiedniej pomocy, aby te mogły zagwarantować opiekę, zarówno materialną jak i duchową - w razie konieczności także za pomocą odpowiednich struktur duszpasterskich - chorym, uchodźcom, emigrantom, imigrantom, bezpaństwowcom, robotnikom okresowym, koczownikom i innym potrzebującym (art. $3 \S 3$ Statutu).

Z powyższej analizy wynika, że zakres kompetencji oraz struktura wewnętrzna tej nowopowstałej instytucji ściśle związana jest z zagwarantowaniem podstawowych praw człowieka oraz ich ochroną. $W$ tej bowiem materii zawiera się moralny aspekt zintegrowanego rozwoju człowieka ${ }^{21}$. Ojciec Święty Franciszek dodaje ponadto, że głównym zadaniem Dykasterii jest integrowanie: „Chodzi o integrowanie różnych narodów ziemi. Obowiązek solidarności wymaga od nas poszukiwania sprawiedliwych sposobów dzielenia się, aby nie było tej dramatycznej nierównomierności między tymi, którzy mają zbyt dużo, a tymi, co nie mają nic; między

${ }^{21}$ Zob. M. Stępniak, Rozwój człowieka - rozwój świata - refleksja w rocznice wielkich papieskich encyklik społecznych, „Annales. Etyka w Życiu Gospodarczym” 2008, t. 11, nr 1, s. 155. 
odrzucającymi a odrzuconymi. Tylko droga integracji między narodami zapewnia ludzkości przyszłość pokojową i pełną nadziei"22.

Słowa kluczowe: dykasteria, prawa człowieka, kuria rzymska, Biskup Rzy$\mathrm{mu}$

\section{Bibliografia}

\section{Źródła prawa}

Benedictus XVI, Litterae encyclicae "Caritas in Veritate" de humana integra progressione in caritate veritateque. 29.06.2009, AAS 101(2009) 641-709.

Benedykt XVI, Encyklika "Caritas in Veritate" Ojca Świętego Benedykta XVI do Biskupów, Prezbiterów i Diakonów, do osób konsekrowanych i wszystkich ludzi dobrej woli o integralnym rozwoju ludzkim w miłości i prawdzie, Skultuna 2012.

Codex Iuris Canonici auctoritate Ioannis Pauli PP. II promulgatus. 25.01.1983, AAS 75(1983), pars II, 1-324.

Francesco, Statuto del Dicastero per il servizio dello sviluppo umano integrale. 17.08.2016, „L'Osservatore Romano" 1.09.2016, s. 6.

Franciscus, Adhortatio apostolica "Evangelii gaudium". 24.11.2013, AAS 105(2013) 1019-1137.

Franciscus, Litterae encyclicae "Laudato si"' de communi domo colenda. 25.05.2015, AAS 107(2015) 847-945.

Franciscus, Litterae apostolicae motu proprio datae "Humanam progressionem" quibus Dicasterium ad integram humanam progressionem fovendam constituitur. 17.08.2016, „L'Osservatore Romano” 1.09.2016, s. 6.

Franciscus, Litterae apostolicae motu proprio datae "Sedula Mater" quibus dicasterium pro laicis, familia et vita constituitur. 15.08.2016, „L'Osservatore Romano" 17-18.08.2016, s. 8.

Franciszek, Adhortacja apostolska "Evangelii gaudium” o głoszeniu Ewangelii w dzisiejszym świecie, Kraków 2014.

Franciszek, Encyklika "Laudato si"' poświęcona trosce o wspólny dom, Częstochowa 2015.

${ }^{22}$ Francis, Speech address of His Holiness pope Francis to the participants in the conference organized by the Dicastery for promoting integral human development, marking the 50th anniversary of the encyclical "Populorum progressio". 4.04.2017, http://w2.vatican.va/content/ francesco/en/speeches/2017/april/documents/ papa-francesco [dostęp: 2.10 .2017 r.]; tekst w j. polskim: Franciszek, Integralny rozwój warunkiem sprawiedliwego świata, http://niedziela. pl/artykul/28078/Franciszek-integralny-rozwoj-warunkiem [dostęp: 2.10.2017 r.]. 
Franciszek, Integralny rozwój człowieka w świetle ewangelii. List apostolski w formie «motu proprio», którym ustanawia Dykasterię ds. Integralnego Rozwoju Człowieka, „L'Osservatore Romano” [wyd. pol.] 36(2016), nr 9, s. 8.

Franciszek, Kościót, troskliwa Matka. List apostolski w formie «motu proprio», na którego mocy zostaje ustanowiona Dykasteria ds. Świeckich, Rodziny i Życia, „L'Osservatore Romano" [wyd. pol.] 36(2016), nr 9, s. 8.

Innocentus VIII, Non debet reprehensibile. 31.12.1487, [w:] Bullarum Diplomatum et Privilegiorum Sanctorum Romanum Pontificum, t. 5, Augustae Taurinorum, Seb. Franco et Henrico Dalmazzo Editoribus, 1860, s. 330-339.

Ioannes Paulus II, Constitutio apostolica "Pastor Bonus". 28.06.1988, AAS 80(1988) 841-912.

Ioannes Paulus II, Legge sugli archivi della Santa Sede. 21.03.2005, AAS 97(2005) 355-376.

Ioannes Paulus II, Litterae apostolicae "motu proprio" datae "Socialium scientiarum" quibus Pontificia Academia Scientiarum Socialium constituitur. 1.01.1994, AAS 86(1994) 209-212.

Jan Paweł II, Konstytucja apostolska o Kurii Rzymskiej "Pastor Bonus", [w:] W. Kasprzak, M. Sitarz (red.), Ustrój hierarchiczny Kościoła. Wybór źródet, Lublin 2006, s. 217-257.

Jan Paweł II, List apostolski "motu proprio", którym Ojciec Święty ustanawia Papieska Akademię Nauk Społecznych, "L'Osservatore Romano" [wyd. pol.] 15(1994), nr 3, s. 39-40.

Kodeks Prawa Kanonicznego. Przekład polski zatwierdzony przez Konferencję Episkopatu, Poznań 1984.

Paulus VI, Constitutio apostolica de Romana Curia "Regimini Ecclesiae Universae". 15.08.1967, AAS 59(1967) 885-928.

Paulus VI, Litterae encyclicae "Populorum progressio". Ad Episcopos, ad Sacerdotes, ad Religiosos, ad Christifideles totius Catholici Orbis, itemque ad universos bonae voluntatis homines: de populorum progressione promovenda. 26.03.1967, AAS 59(1967) 257-299.

Paweł VI, Konstytucja apostolska "Regimini Ecclesiae Universae”, [w:] W. Kacprzyk, M. Sitarz (red.), Ustrój hierarchiczny Kościoła. Wybór źródet, Lublin 2006, s. 166-196.

Paweł VI, Populorum progressio, Wrocław 1999.

Sacrosanctum Concilium Oecumenicum Vaticanum II, Decretum de pastorali episcoporum munere in Ecclesia "Christus Dominus". 28.10.1965, AAS 58(1966) 673-696.

Secretaria Status, Decreto. 2.05.2012, AAS 104(2012) 919-969.

Secretaria Status, Regolamento della Commissione indipendente di valutazione per le assunzioni di personale laico presso la Sede Apostolica. 30.11.2012, AAS 105(2013) 84-92.

Secretaria Status, Regolamento Generale della Curia Romana. 30.04.1999, AAS 91(1999) 629-699. 
Sobór Watykański II, Dekret o pasterskich zadaniach biskupów w Kościele "Christus Dominus", [w:] Sobór Watykański II. Konstytucje, dekrety, deklaracje, Poznań 2002, s. 236-258.

\section{Literatura}

Annuuario pontificio per l'anno 2017, Città del Vaticano 2017.

Antoniewicz M., Integralny rozwój człowieka w ujęciu "Caritas in veritate" Benedykta XVI, „Studia Gnesnensia” 2010, t. 24, s. 265-277.

Franciszek, Integralny rozwój warunkiem sprawiedliwego świata, http://nie= dziela.pl/artykul/28078/Franciszek-integralny-rozwoj-warunkiem [dostęp: 2.10.2017 r.].

Franciszek, Przyjmować, chronić, promować i integrować imigrantów i uchodźców. Orędzie papieża Franciszka na Światowy Dzień Migranta i Uchodźcy 2018 r. 15.08.2017, „L'Osservatore Romano” [wyd. pol.] 37(2017), nr 9, s. 4-7.

Francis, Speech Address of his Holiness Pope Francis to the Members of the European Confederation and of the World Union of Jesuit Alumni and Alumnae, https://w2.vatican.va/content/francesco/en/speeches/2016/september/documents/ papa-francesco [dostęp: 1.10.2017 r.].

Francis, Speech address of His Holiness pope Francis to the participants in the conference organized by the Dicastery for promoting integral human development, marking the 50th anniversary of the encyclical "Populorum progressio". 4.04.2017, http://w2.vatican.va/content/francesco/en/speeches/2017/april/ documents/ papa-francesco [dostęp: 2.10.2017 r.].

Paupard P., Watykan, Warszawa 1979.

Romanko A., Nowe struktury ekonomiczno-administracyjne w Kurii Rzymskiej, „Roczniki Nauk Prawnych” 2016, nr 3, s. 99-120.

Romanko A, Reforma Urzędu Informacji Finansowej i Instytutu Dzieł Religijnych, „Prawo Kanoniczne" 2016, nr 3, s. 122-142.

Stępniak M., Rozwój człowieka - rozwój świata - refleksja w rocznicę wielkich papieskich encyklik społecznych, „Annales. Etyka w Życiu Gospodarczym” 2008, t. 11, nr 1, s. 149-156.

Sztafrowski E., Kuria Rzymska. Studium historyczno-kanoniczne, Warszawa 1981.

Zanotti A., "A chiare lettere - confronti". A proposito di un diritto canonico periferico: ovvero il rischio della perifericità del diritto canonico, "Stato, Chiese e Pluralismo Confessionale. Rivista telematica" 2017, nr 2, s. 1-18. 


\section{THE STRUCTURE AND JURISDICTION OF THE DICASTERY FOR PROMOTING INTEGRAL HUMAN DEVELOPMENT}

\section{S u m m a r y}

Dicastery for Promoting Integral Human Development will be particularly competent in matters concerning migration, the necessitous, the ill and the excluded, the marginalized and the victims of armed conflicts and natural catastrophes, the prisoners, the unemployed and victims of any form of slavery and torture.

The goal of this article is to show the structure and jurisdiction of the newly created Dicastery, which is a part of the pope's wide plan to reform the Roman Curia in a way that, by answering the needs of the times and the place, allows it to accomplish its main goal of helping the bishop of Rome in dealing with the matters of the universal Church (can. 360). The main goal of the Dicastery is to integrate different nations of the Earth.

Key words: dicastery, human rights, Roman Curia, Bishop of Rome

\section{СТРУКТУРА И КОМПЕТЕНЦИИ ДИКАСТЕРИИ ПО ДЕЛАМ ИНТЕГРАЯЬНОГО РАЗВИТИЯ ЧЕЛОВЕКА}

\section{P e 3 г м e}

Дикастерия по делам содействия интеградьного развития человека будет особенно компетентна в вопросах относительно миграций, нуждающихся, больных и исключенных, маргиналированных и жертв вооруженных конфликтов, а также натуральных катастроф, заключенных, безработных и жертв других форм рабства и пыток. Данная статья имеет за цель показать структуры и компетенции созданой дикастерии, которая вписывается в широкий план римского папы, реформируя Римскую Курию таким способом, чтобы отвечая на потребности времени и места могла она лучше реализовывать свое главное задание, которым является оказание помощи Епископу Рима в улаживании дел повсеместной Церкви (kan. 360). Главным заданием Дикастерии является интегрированность разных народов земли.

Ключевые слова: дикастерия, права человека, римская курия, Епископ Рима 